\title{
FAKTOR-FAKTOR YANG BERHUBUNGAN DENGAN KEMANDIRIAN PUS MENJADI AKSEPTOR KB SUNTIK DI PKM PALAKKA
}

\author{
Muzayyana \\ Program Studi D-III Kebidanan, Stikes Graha Medika Kotamobagu, Jl. Raya AKD, RSI Moonow Lt.2, \\ Mongkonai Barat, Kota Kotamobagu, muzayyanananna@gmail.com
}

Diterima 27 Februari 2020, disetujui 15 April 2020, diterbitkan 30 April 2020

Pengutipan: Muzayyana. (2020). Faktor-Faktor yang Berhubungan dengan Kemandirian PUS Menjadi Akseptor KB Suntik di PKM Palakka Kec. Palakka Kab. Bone .Gema Wiralodra, Vol 11, No 1, Hal 45-58, April 2020

\begin{abstract}
ABSTRAK
Kelompok Pasangan Usia Subur (PUS) merupakan salah satu kelompok yang mendapat perhatian khusus dari pemerintah karena kelompok ini dianggap mampu membantu mengurangi terjadinya kepadatan atau lonjatan penduduk. Jumlah PUS di Wilayah Puskesmas Palakka tahun 2013 sebanyak 1.050 sedangkan tahun 2014 sebanyak 2.041 dengan pencapaian akseptor KB aktif sebanyak 598 peserta dengan rincian metode kontrasepsi sebagai berikut: Pil sebanyak 244 peserta, suntikan sebanyak 265 peserta, Kondom sebanyak 9 peserta, Implant sebanyak 74 peserta, IUD sebanyak 3 peserta dan MO sebanyak 3 peserta. Tingkat kemandirian PUS untuk menjadi akseptor KB masih kurang. Rancangan penelitian deskriptif analitik dengan pendekatan Cross sectional study. Populasi seluruh PUS ber KB suntik yang berada di wilayah puskesmas Palakka Kabupaten Bone. Sampel penelitian sebanyak 31 PUS. Teknik pengambilan sampel yaitu Accidental Sampling. Hasil penelitian pendidikan $(\rho$ value $=0,001)$ dan pengetahuan $(\rho$ value $=0,002)$. Kesimpulan ada hubungan pendidikan dan pengetahuan dengan kemandirian PUS menggunakan KB suntik.
\end{abstract}

Kata Kunci : Pasangan usia subur, KB suntik

\begin{abstract}
The Fertile Age Group (PUS) is one of the groups that received special attention from the government because this group was considered capable of helping to reduce population density or spikes. The number of EFAs in the Palakka Community Health Center in 2013 was 1,050 while in 2014 there were 2,041 with the achievement of active KB acceptors as many as 598 participants with the following contraceptive methods: Pill as many as 244 participants, injections of 265 participants, Condoms as many as 9 participants, Implants as many as 74 participants, IUD with 3 participants and MO with 3 participants. The level of independence of EFA to become a KB acceptor is still lacking. Descriptive analytic research design with a cross sectional study approach. The entire population of EFA is injecting family planning in the area of Palakka Puskesmas, Bone Regency. The research sample was 31 EFAs. The sampling technique is accidental sampling. Educational research results ( $\rho$ value $=0.001)$ and knowledge $(\rho$ value $=0.002)$. Conclusion there is a relationship between education and knowledge with the independence of EFA using injection $\mathrm{KB}$.
\end{abstract}

Keywords: couples of childbearing age, injecting contraception

\section{PENDAHULUAN}

Diterbitkan oleh:

Universitas Wiralodra

Jln. Ir. H. Juanda Km 3 Indramayu, Jawa Barat 
Kelompok Pasangan Usia Subur (PUS) merupakan salah satu kelompok yang mendapat perhatian khusus dari pemerintah karena kelompok ini dianggap mampu membantu mengurangi terjadinya kepadatan atau lonjatan penduduk serta dapat mendukung motto "Dua Anak Cukup". Adanya kesadaran yang tinggi dari kelompok PUS membuat kesejahteraan sebuah wilayah Negara untuk mencapai kemakmuran dapat terwujud (BKKBN, 2008). Tujuan gerakan Keluarga Berencana (KB) Nasional ialah mewujudkan Keluarga Kecil Bahagia Sejahtera yang menjadi dasar bagi terwujudnya masyarakat yang sejahtera melalui pengendalian kelahiran dan pertumbuhan penduduk Indonesia. Sasaran gerakan KB Nasional adalah : (1) Pasangan usia subur (PUS) dengan prioritas PUS muda dengan paritas rendah, (2) Generasi muda dan purna PUS, (3) Pelaksana dan pengelola KB, dan (4) Sasaran wilayah atau wilayah dengan laju pertumbuhan penduduk tinggi dan wilayah khusus seperti sentra industri, pemukiman padat, daerah kumuh, daerah pantai dan daerah terpencil (Winkjosastro, 2010).

Menurut Prasti dalam Japaruddin (2011), kecenderungan pemilihan alat kontrasepsi pada PUS dipengaruhi oleh banyak hal, baik itu faktor suami/istri, umur, pendidikan, pekerjaan, dukungan keluarga, pengetahuan, pendapatan/ penghasilan, jumlah anak yang diinginkan, efek samping serta faktor yang juga berpengaruh adalah pelayanan kesehatan khususnya KB yang meliputi ketersediaan alat kontrasepsi, jarak dan pelayanan dari petugas kesehatan (Japaruddin, 2011).

Melihat realita yang ada saat ini, masyarakat cenderung memilih kontrasepsi dengan tingkat resiko yang rendah dan tidak berpengaruh pada kehidupan sosial serta kelangsungan hidup. Oleh karena itu, maka diharapkan agar pemerintah menjadikan KB sebagai gerakan yang mampu menghimpun dan mengajak segenap potensi masyarakat untuk berpartisipasi aktif dalam mewujudkan norma keluarga kecil bahagia dan sejahtera. Serta meningkatkan mutu kehidupan masyarakat, sebagai upaya pengendalian pertumbuhan penduduk selain faktor pendidikan, kesehatan, ekonomi, pembangunan daerah dan penciptaan lapangan kerja (Akbar, 2018).

Secara nasional pencapaian Keluarga berencana (KB) di Indonesia sampai Desember 2013 ada sekitar 29 juta akseptor atau sekitar 61,4 \%, dengan pengguna KB suntik sebesar 31,6\%. Sedangkan yang memakai pil hanya 13,2\%, memakai IUD (Intra

Diterbitkan oleh: 
Uterine Device) atau spiral 4,8 \%, implant 2,8 \%, dan kondom 1,3\%, sisanya vasektomi dan tubektomi (BKKBN, 2014).

Daerah Sulawesi Selatan menurut data statistik BKKBN sampai akhir Desember 2013, Pencapaian Akseptor KB baru adalah 256.850 peserta atau 99,18 \% dari Perkiraan Permintaan Masyarakat (PPM). Untuk metode kontrasepsi yang paling banyak digunakan adalah suntikan sebanyak 118.820 peserta, Pil sebanyak 94.259 peserta, Implant sebanyak 19.119 peserta, Kondom sebanyak 16.986 peserta, serta Intra Uterina Device (IUD) sebanyak 3.824 peserta (Dinkes Provinsi Sulawesi Selatan, 2013).

Keadaan akseptor KB aktif di Kabupaten Bone Tahun 2013 sebanyak 30.245 dengan penggunaan KB suntik sebanyak 12.126 peserta,pil 410 peserta,implant 10.102,kondom 232 peserta dan IUD 201 peserta,sedangkan pada Tahun 2014 dari bulan Januari-September 2014 adalah sebanyak 33.171 peserta atau 32,43\%.Penggunaan suntikan paling banyak yaitu 15.507 peserta ,pil sebanyak 5.878 peserta,implant sebanyak 19.783 peserta ,kondom sebanyak 1.100 peserta dan IUD sebanyak 1.101 peserta (Dinkes Provinsi Sulawesi Selatan, 2014).

Data BKKBN Kabupaten Bone sampai dengan bulan September Tahun 2014, jumlah PUS meningkat sebanyak 5.424 peserta dengan persentase peserta akseptor KB aktif sebanyak 4.513 peserta. Pencapaian metode kontrasepsinya adalah sebagai berikut : Suntikan sebanyak 1.391 peserta, Pil sebanyak 1.374 peserta, Implant sebanyak 164 peserta, kondom sebanyak 77 peserta, IUD sebanyak 66 peserta, dan MO sebanyak 24 peserta (BKKBN Kabupaten Bone, 2014).

Jumlah PUS di Wilayah Puskesmas Palakka Tahun 2013 sebanyak 1.050 sedangkan bulan Januari-November tahun 2014 sebanyak 2.041 dengan pencapaian akseptor KB aktif sebanyak 598 peserta dengan rincian metode kontrasepsi sebagai berikut: Pil sebanyak 244 peserta, suntikan sebanyak 265 peserta, Kondom sebanyak 9 peserta, Implant sebanyak 74 peserta, IUD sebanyak 3 peserta dan MO sebanyak 3 peserta (Puskesmas Palakka, 2014).

Dari data di atas, dapat diketahui bahwa tingkat kemandirian PUS untuk menjadi akseptor KB masih kurang. Ini dilihat dari masih kurangnya PUS yang menjadi akseptor.

Diterbitkan oleh: 
Maka dari itu peneliti tertarik untuk melihat sejauh mana faktor yang berhubungan dengan kemandirian pasangan usia subur menjadi akseptor KB di Kecamatan sendiri, baik PUS peserta KB aktif maupun PUS bukan peserta KB sehingga memahami benar manfaat KB dan sebagian besar telah mandiri untuk menggunakannya. Sesuai dengan penelitian yang akan dilakukan, ini dipengaruhi oleh tingkat pengetahuan dan efek samping yang dirasakan PUS, tanpa memandang status pendidikan ataupun pekerjaan mereka.

\section{METODE PENELITIAN}

Jenis penelitian ini yang digunakan adalah observasional analitik dengan pendekatan Cross sectional study untuk mengetahui faktor-faktor yang berhubungan. Populasi dalam penelitian adalah seluruh PUS ber KB suntik yang berada di Wilayah Puskesmas Palakka Kabupaten Bone dalam periode Januari-November 2014 sebanyak 265 peserta. Sampel dalam penelitian ini adalah PUS yang datang berkunjung ke Puskesmas Palakka Kabupaten Bone sebanyak 31 responden. Penelitian ini menggunakan teknik Accidental Sampling. Pengumpulan data dengan menggunakan data primer dengan menggunakan kuisioner. Analisis data menggunakan uji Chi Square.

\section{HASIL DAN PEMBAHASAN}

\section{Hasil}

Penelitian dilakukan terhadap 31 sampel PUS suntik. Adapun yang diteliti terdiri dari variabel dependen yaitu kemandirian PUS menggunakan KB suntik dan variabel independen terdiri dari pendidikan, pengetahuan, dan pekerjaan terhadap kemadirian PUS menggunakan $\mathrm{KB}$ suntik

\section{Tabel 1. Analisi Bivariat}

Diterbitkan oleh:

Universitas Wiralodra

Jln. Ir. H. Juanda Km 3 Indramayu, Jawa Barat 
Distribusi Responden Berdasarkan Hubungan Pendidikan Dengan Kemandirian PUS Menjadi Akseptor KB Suntik Di Wilayah Puskesmas Palakka Desember Tahun 2014

\begin{tabular}{ccccccc}
\hline $\begin{array}{c}\text { Pendidikan } \\
\text { Terakhir }\end{array}$ & & Kemandirian & PUS & Total \\
& Mandiri & \multicolumn{5}{c}{$\begin{array}{c}\text { Tidak } \\
\text { mandiri }\end{array}$} \\
& $\mathrm{N}$ & $\%$ & $\mathrm{~N}$ & $\%$ & $\mathrm{~N}$ & $\%$ \\
Tinggi & 16 & 88,9 & 2 & 11,1 & 18 & 100 \\
Rendah & 3 & 23,1 & 10 & 76,9 & 13 & 100 \\
Total & 19 & 61,3 & 12 & 38,7 & 31 & 100 \\
\hline
\end{tabular}

Berdasarkan hasil analisis bivariat pada Tabel 1 menunjukkan bahwa dari 31 jumlah pasangan usia subur di Wilayah Puskesmas Palakka sebanyak 16 Pasangan Usia Subur $(88,9 \%)$ mempunyai pendidikan tinggi, mandiri untuk menjadi akseptor Keluarga Berencana (KB) Suntik dan sebanyak 2 PUS $(11,1 \%)$ yang mempunyai pendidikan tinggi tidak mandiri untuk menjadi akseptor Keluarga Berencana (KB) Suntik. Sedangkan 3 PUS $(23,1 \%)$ mempunyai pendidikan rendah, mandiri untuk menjadi akseptor Keluarga Berencana (KB) Suntik dan sebanyak 10 PUS (76,9\%) yang mempunyai pendidikan rendah, tidak mandiri untuk menjadi akseptor KB Suntik. Hasil uji Chi-square diperoleh nilai $\mathrm{p}=0,001(<\alpha=0,05)$.

Tabel 2.

Distribusi Responden Berdasarkan Hubungan Pengetahuan Dengan Kemandirian PUS Menjadi Akseptor KB Suntik Di WilayahPuskesmas Palakka Kab. BoneDesember Tahun 2014

\begin{tabular}{ccccccc}
\hline Pengetahuan & & Kemandirian & PUS & Total \\
& & Mandiri & \multicolumn{5}{c}{ Tidak } \\
& & $\%$ & mandiri & & \\
& $\mathrm{N}$ & 82,4 & 3 & 17,6 & 17 & 100 \\
Cukup & 14 & 35,7 & 9 & 64,3 & 14 & 100 \\
Kurang & 15 & 61,3 & 12 & 38,7 & 31 & 100 \\
Total & 19 & & & & & \\
\hline
\end{tabular}

Berdasarkan hasil analisis bivariat pada Tabel 2 pada variabel pengetahuan menunjukkan 14 Pasangan Usia Subur $(82,4 \%)$ mempunyai pengetahuan cukup, mandiri

Diterbitkan oleh:

Universitas Wiralodra

Jln. Ir. H. Juanda Km 3 Indramayu, Jawa Barat 
untuk menjadi akseptor Keluarga Berencana (KB) Suntik dan sebanyak 3 PUS $(11,1 \%)$ yang mempunyai pengetahuan cukup mandiri untuk menjadi akseptor Keluarga Berencana (KB) Suntik. Sedangkan 15 PUS (35,7\%) mempunyai pengetahuan kurang, mandiri untuk menjadi akseptor Keluarga Berencana (KB) Suntik dan sebanyak 9 PUS (64,3\%) yang mempunyai pendidikan rendah, tidak mandiri untuk menjadi akseptor KB Suntik. Hasil uji Chi-square diperoleh nilai $\mathrm{p}=0,002(<\alpha=0,05)$.

Tabel 3 Distribusi Responden Berdasarkan Hubungan Pekerjaan Dengan Kemandirian PUS Menjadi Akseptor KB Suntik

Di Wilayah Puskesmas Palakka Kab. Bone

Desember Tahun 2014

\begin{tabular}{|c|c|c|c|c|c|c|}
\hline \multirow{3}{*}{$\begin{array}{c}\text { Jenis } \\
\text { pekerjaan }\end{array}$} & & Kemandirian & PUS & \multicolumn{3}{|c|}{ Total } \\
\hline & Mandiri & & $\begin{array}{c}\text { Tidak } \\
\text { mandiri }\end{array}$ & & & \\
\hline & $\mathrm{N}$ & $\%$ & $\mathrm{~N}$ & $\%$ & $\mathrm{~N}$ & $\%$ \\
\hline Bekerja & 11 & 78,5 & 3 & 21,5 & 14 & 100 \\
\hline Tidak bekerja & 8 & 47,0 & 9 & 52,9 & 17 & 100 \\
\hline Total & 19 & 61,3 & 12 & 38,7 & 31 & 100 \\
\hline
\end{tabular}

Berdasarkan hasil analisis bivariat pada Tabel 3 menunjukkan bahwa dari 31 pasangan usia subur di Wilayah Puskesmas Palakka sebanyak 11 PUS (78,5\%) yang bekerja, mandiri untuk menjadi akseptor Keluarga Berencana (KB) Suntik dan sebanyak 3 PUS $(21,5 \%)$ yang bekerja, tidak madiri untuk menjadi akseptor KB Suntik. Sedangkan 8 PUS (47,0\%) yang tidak bekerja, mandiri untuk menjadi akseptor KB Suntik dan sebanyak 9 PUS $(52,9 \%)$ yang tidak bekerja, tidak mandiri untuk menjadi akseptor KB Suntik. Hasil uji Chi-square diperoleh nilai $\mathrm{p}=0,155(>\alpha=0,05)$.

\section{Pembahasan}

a. Hubungan Pendidikan dengan Kemandirian PUS Menjadi Akseptor Keluarga Berencana (KB) Suntik

Semakin tinggi pendidikan akan jelas mempengaruhi pribadi seseorang dalam berpendapat, berpikir, bersikap, lebih mandiri dan rasional dalam mengambil keputusan dan tindakan. Hal ini juga akan mempengaruhi secara langsung seseorang dalam hal pengetahuannya akan orientasi hidupnya termasuk dalam

Diterbitkan oleh: 
merencanakan keluarganya. Pendidikan juga akan meningkatkan kesadaran wanita terhadap manfaat yang dapat dinikmati bila ia mempunyai jumlah anak sedikit. Tinggi rendahnya tingkat sosial ekonomi yang dimiliki oleh responden, membuat responden sangat susah untuk membiayai atau melanjutkan pendidikannya, disatu sisi pemenuhan kebutuhan sehari-hari sangat penting untuk dipenuhi.

Hasil Penelitian sebelumnya yang dilakukan oleh Lasambo (2006) yang menyatakan bahwa ada hubungan antara pendidikan dengan tingkat kemandirian ber-KB, yaitu responden yang berpendidikan cukup mempunyai tingkat mandiri penuh 88 (53,99\%), sedangkan yang berpendidikan kurang mempunyai tingkat mandiri tidak penuh 17 (30,36\%). Hal ini sejalan dengan penelitian yang dilakukan oleh Darmawati (2003), bahwa semakin tinggi pendidikan seseorang semakin mudah menerima KB. (Lasambo, 2006).

Dari hasil penelitan di Puskesmas Palakka Kab.Bone tahun 2014 tabel 5.7 diperoleh data bahwa PUS yang memiliki pendidikan tinggi, mandiri untuk menjadi akseptor KB Suntik sebanyak 16 PUS (88,9\%). Selain itu terdapat juga PUS yang memiliki pendidikan rendah, mandiri untuk menjadi akseptor KB Suntik sebanyak 3 PUS $(23,1 \%) \quad$ Berdasarkan uji statistik dengan uji Chi-square (continuity correction) didapatkan nilai $\mathrm{p}<\alpha(\mathrm{p}=0,001(<\alpha=0,05))$, maka Ho di tolak, yang artinya ada hubungan yang bermakna antara pendidikan dengan kemandirian PUS menjadi akseptor KB Suntik di Wilayah Puskesmas Palakka Kab. Bone pada bulan Desember 2014.

Hasil penelitian ini juga sejalan dengan pendapat Ngatimin (1989), menyatakan bahwa tingkat pendidikan formal yang penuh diperoleh seseorang akan meningkatkan daya nalarnya dan dasar pengembangan daya nalar memudahkan seseorang untuk menerima motivasi. Pendidikan yang rendah menyebabkan sulitnya masyarakat menerima penyuluhan kesehatan. Dengan pendidikan yang cukup diharapkan masyarakat lebih mudah untuk memahami informasi yang disodorkan kepadanya sehingga dalam pelaksanaan suatu program tidak banyak menemui kesulitan (Ngatimin, 2006).

Diterbitkan oleh: 
b. Hubungan Pengetahuan dengan Kemandirian PUS Menjadi Akseptor Keluarga Berencana (KB) Suntik

Secara teoritis diketahui bahwa pengetahuan mempunyai kontribusi yang besar dalam mengubah perilaku seseorang untuk berbuat sesuatu. Berdasarkan hasil penelitian didapatkan bahwa, semakin tinggi tingkat pengetahuan seseorang tentang alat kontrasepsi maka akan cenderung memilih alat kontrasepsi suntik. Hal ini disebabkan karena tingkat pendidikan yang dimiliki oleh responden sebagian besar cukup tinggi dan ada pula responden yang masih berpendidikan rendah, selain itu ada beberapa responden yang memilih alat kontrasepsi suntik bukan karena dia tahu tentang alat kontrasepsi secara umum melainkan karena responden tersebut mengikuti alat kontrasepsi yang digunakan oleh teman terdekat atau saudaranya. Selain itu kurangnya sosialisasi yang dilakukan oleh petugas kesehatan tentang KB sehingga responden sangat terbatas dalam mendapatkan informasi tentang alat kontrasepsi serta masih bersifat pasif artinya petugas kesehatan menunggu pasien untuk datang di puskesmas atau rumah sakit.

Hasil penelitian sebelumnya yang dilakukan oleh A. Latief Tjokke menyatakan bahwa perbedaan frekuensi pengetahuan tentang tujuan KB menurut pengetahuan responden adalah bermakna (Tjokke A. L, 2006). Hasil penelitian ini juga sejalan dengan penelitian yang dilakukan oleh Wahidah (2005) di PT. Indofood Sukses Makmur Makassar, yang menyimpulkan bahwa sebagian besar responden yang memakai alat kontrasepsi, memiliki tingkat pengetahuan yang cukup (Wahidah, 2005).

Dari hasil penelitan di Puskesmas Palakka Kab.Bone tahun 2014 tabel 5.8 diperoleh data bahwa PUS yang memiliki pengetahuan cukup dan mandiri untuk menjadi akseptor KB Suntik sebanyak 14 PUS (82,4\%). Selain itu terdapat juga PUS yang memiliki pengetahuan kurang tetapi mandiri untuk menjadi akseptor KB Suntik sebanyak 5 PUS (35,7\%). Berdasarkan uji statistik Chi-square (continuity correction) didapatkan nilai $\mathrm{p}<\alpha(\mathrm{p}=0,022(<\alpha=0,05))$, maka Ho ditolak, berarti ada hubungan yang bermakna antara pengetahuan dengan kemandirian PUS menjadi akseptor KB Suntik di Wilayah Puskesmas Palakka Kabupaten Bone. 
Hasil penelitian sebelumnya sejalan dengan penelitian ini. Hal ini menunjukkan bahwa tingkat pengetahuan merupakan salah satu faktor yang mempengaruhi kemandirian seseorang, khususnya PUS dalam ber-KB suntik. Semakin besar tingkat pengetahuan seseorang mengenai manfaat ber-KB, maka semakin besar pula motivasi orang tersebut untuk ber-KB.

Hasil penelitian ini didukung oleh pendapat H.M.Rusli Ngatimin (1987), yang menyatakan bahwa perubahan pengetahuan diharapkan akan merubah sikap dan bila sikap telah berubah, ini merupakan predisposisi untuk perubahan perilaku. Adanya perubahan sikap dan perilaku didahului oleh adanya persepsi yang tepat pada suatu objek. Dalam hal ini pemberian informasi-informasi mengenai program KB perlu ditingkatkan melalui berbagai jalur, seperti media massa, BKIA, maupun melalui organisasi yang ada dalam masyarakat seperti PKK, kelompok dasawisma serta kelompok akseptor (Ngatimin, 2006). Serta di dukung pula pendapat Poedjowijatna yang membagi pengetahuan menjadi dua macam, yaitu pengetahuan khusus dan pengetahuan umum. Yang dimaksud dengan pengetahuan khusus adalah pengetahuan mengeani sesuatu saja sedangkan pengetahuan umum berlaku bagi seluruh macam dan masing-masing macamnya. Baik pengetahuan khusus dan pengetahuan umum, keduanya menjadi milik manusia berdasarkan pengalaman (Santoso \& Akbar, 2018). Entah pengalaman sendiri atau pengalaman orang lain. Jadi, pengetahuan merupakan khasanah pengetahuan mental yang secara langsung atau tidak langsung memperkaya kehidupan (Subaeda, 2005).

c. Hubungan Jenis Pekerjaan dengan Kemandiran PUS menjadi akseptor Keluarga Berencana (KB) Suntik

Pekerjaan dapat mempengaruhi kepribadian seseorang, karena tiap hari harus bergelut dengan tugas-tugas yang dihadapinya maka terjadilah the second nature padanya (Gunawan, 2000). Misalnya dengan bekerja seorang wanita yang sudah menikah akan mempunyai dua lingkungan yaitu dalam keluarga dan lingkungan di lapangan pekerjaan, sehingga mempengaruhi Dia dalam memilih alat kontrasepsi. 
Hasil penelitian sebelumnya yang dilakukan oleh Sitti Rachmah (1995) di Kabupaten Maros menyatakan bahwa ada hubungan yang bermakna antara pendapatan dengan keikutsertaan PUS dalam program KB mandiri (Lasambo, 2006). Kemudian penelitian yang dilakukan oleh H. Sirajuddin, BM dan A. Latief Tjokke pada Survey Pencapaian Program KB Serta Pengaruhnya Terhadap Fertilitas di Sulawesi Selatan menyatakan bahwa pekerjaan PUS berpengaruh terhadap pencapaian program KB. (Tjokke, A. L, 2006).

Hasil penelitian ini juga sesuai dengan penelitian Lasambo (2006) yang berjudul beberapa faktor yang berhubungan dengan tingkat kemandirian peserta $\mathrm{KB}$ di Kelurahan Kema Raya Kec. Kendari Kodya Kendari menyatakan bahwa ada hubungan antara pekerjaan dengan tingkat kemandirian ber-KB. Adanya hubungan tersebut menunjukkan bahwa semakin tinggi tingkat ekonomi seseorang semakin tinggi pula tingkat kemandiriannya ber-KB (Lasambo, 2006).

Dari hasil penelitan di Puskesmas Palakka Kab.Bone tahun 2014 tabel 5.9 diperoleh data bahwa PUS yang bekerja dan mandiri untuk menjadi akseptor KB Suntik sebanyak 11 PUS (78,5\%). Selain itu, terdapat juga PUS yang tidak bekerja, mandiri untuk menjadi akseptor KB Suntik sebanyak 8 PUS (47,0\%). Berdasarkan uji statistik dengan menggunakan uji Chi-square (continuity correction) didapatkan dengan nilai $\mathrm{p}>\alpha$ (nilai $\mathrm{p}=0,155(>\alpha=0,05)$ ), maka Ho diterima, berarti tidak ada hubungan yang bermakna antara pekerjaan dengan kemandirian PUS menjadi akseptor KB Suntik di Wilayah Puskesmas Palakka Kabupaten Bone.

Hasil penelitian sebelumnya tidak sejalan dengan penelitian ini. Hal ini mungkin disebabkan oleh cara pengukuran atau penilaian yang berbeda, jumlah sampel yang tidak sama, ataupun metode pendekatan ke masyarakat yang berbeda dan sebagainya. Hasil penelitian ini tidak sejalan dengan teori yang dikemukakan oleh Noor, yang mengatakan bahwa pekerjaan adalah sesuatu yang dilakukan, diperbuat, dikerjakan untuk mendapatkan nafkah atau menghasilkan uang. Jadi, pekerjaan yang dilakukan akan mempengaruhi besar kecilnya pendapatan seseorang, tetap atau tidaknya menerima penghasilan dan waktu menerima gaji atau upah "Labour Force Concept" yang digolongkan bekerja adalah mereka yang

Diterbitkan oleh: 
melakukan pekerjaan untuk menghasilkan barang-barang atau jasa-jasa dengan tujuan untuk memperoleh penghasilan atau keuntungan bila mereka bekerja penuh maupun tidak bekerja penuh (Noor, 2007).

\section{KESIMPULAN}

Terdapat hubungan pendidikan dan pengetahuan dengan kemandirian pasangan usia subur menjadi akseptor KB suntik di puskesmas Palakka Kecamatan Palakka, Kab.Bone. Sedangkan pekerjaan tidak terdapat hubungan.

\section{SARAN}

Di harapkan kepada petugas untuk memberikan informasi karena tingkat pendidikan ,pengetahuan, dan pekerjaan seseorang berbeda-beda, ada yang berpendidikan tinggi ada yang berpendidikan rendah .Dengan pendidikan yang cukup diharapkan masyarakat lebih mudah untuk memahami informasi yang disodorkan kepadanya sehingga dalam pelaksanaan suatu program tidak banyak menemui kesulitan dan mandiri dalam kegiatan ber KB, Semakin besar tingkat pengetahuan seseorang mengenai manfaat ber-KB , maka semakin besar pula motivasi orang tersebut untuk ber-KB dengan mandiri.

\section{UCAPAN TERIMAKASIH}

Peneliti mengucapkan terimakasih kepada Kepala Puskesmas Palakka, Kecamatan Palakka, Kabupaten Bone dan Jajarannya serta para PUS yang telah membantu peneliti demi kelancaran pelaksanaan penelitian ini.

\section{DAFTAR PUSTAKA}

Akbar, H. (2018). Faktor Yang Berhubungan Dengan Penggunaan Alat Kontrasepsi Pada Pasangan Usia Subur Di Desa Lohbener Kabupaten Indramayu. Gema Wiralodra, 9(2), 164-182. https://doi.org/10.31943/gemawiralodra.vol9.iss2.350

Anita, L., Kusmiyati., Robin, D. 2014. Faktor-Faktor yang Berhubungan dengan Pemilihan Kontrasepsi Pasangan Usia Subur di Puskesmas Damau Kabupaten Talaud. Jurnal Ilmiah Bidan, Vol.2 No.1. 
Arum, D. N. S., 2008. Panduan Lengkap Pelayanan KB Terkini. Mitra Cendikia Press : Jogjakarta.

Asriani. (2006). Faktor-Faktor Yang Berhubungan Dengan Pemilihan Penolong Persalinan Oleh Ibu Bersalin di Wilayah Puskesmas Barombong Kelurahan Barombong Tahun 2006. Skripsi FK UNHAS. Makassar.

BKKBN. (2004). Apa Yang Harus Anda Ketahui Tentang Alat Kontrasepsi. Sub Dinas Penyuluhan Kesehatan.

BKKBN Propinsi Sul-Sel. (2005). Gerakan Pembangunan Keluarga Sejahtera. Ujung Pandang.

BKKBN Kabupaten Wajo (2010). Laporan Bulanan Pengendalian Lapangan Program KB Nasional Tingkat Kecamatan. Wajo.

Dinas Kesehatan Provinsi Sulawesi Selatan. (2010). Profil Kesehatan Sulawesi Selatan Tahun 2010. Diakses 25 Juli 2011 pada http://www.dinkes-sulsel.go.id.

Dharmayanti, N.U.E. 2011. Faktor-Faktor yang Berhubungan dengan Penggunaan Kontrasepsi oleh PUS di Desa Paya Lambing Kecamatan, Padang Hilir, Kota Tebing Tinggi, Akademi Keperawatan Bina Husada Tebing Tinggi, Sumatera Utara. Jurnal Kamilah, Volume III No. 5 April 2011.

Dihra A. J., (2011). Faktor-Faktor Yang Berhubungan Dengan Pemberian ASI Eksklusif Pada Anak Balita Di RSUD Tenriawaru, Bone Tahun 2011. Skripsi FK UNHAS. Makassar.

Hasbullah. (2004). Dasar-Dasar Ilmu Pendidikan. Raja Grafindo Persada : Jakarta.

Hidayat, A. A. L., (2007). Riset Keperawatan dan Teknik Penulisan Ilmiah, Edisi II. Salemba Medika : Jakarta.

Irawan, W. (2007). Faktor2 Yang Berhubungan Dengan Pemilihan Alat Kontrasepsi Suntik Di Puskesmas Kassi-Kassi Makassar Tahun 2007. Skripsi FK UNHAS. Makassar.

Japaruddin. (2007). Karakteristik Akseptor KB pada Pasangan Usia Subur (PUS) di wilayah Kerja Puskesmas Towuti Desa Asuli Kecamatan Towuti Kabupaten Luwu Timur Tahun 2007. Skripsi FKM UMI. Makassar.

Koesnadi. (2003). Seksualitas \& Alat Kontrasepsi. Usaha Nasional : Surabaya.

Lasambo (2006). Beberapa Faktor Yang Berhubungan Dengan Tingkat Kemandirian di Desa Pallangga Kab. Gowa. Skripsi FK UNHAS. Makassar.

Mansjoer A, dkk. (2005). Kapita Selekta Kedokteran Edisi Ketiga. Media Aesculapius, Fakultas Kedokteran UI : Jakarta.

Diterbitkan oleh:

Universitas Wiralodra

Jln. Ir. H. Juanda Km 3 Indramayu, Jawa Barat 
Maryatun. 2009. Analisis Faktor-Faktor pada Ibu yang Berpengaruh Terhadap Pemakaian Metode Kontrasepsi IUD di Kabupaten Sukoharjo. STIK Aisyiyah Surakarta, Eksplanasi Volume 4 Nomor 8 Edisi Oktober 2009.

Manuaba, I.B.G. (2005). Ilmu Kebidanan, Penyakit Kandungan \& Keluarga Berencana Untuk Pendidikan Kebidanan. EGC : Jakarta.

Ngatimin. (2004). Mengenal Health Education dan Behavioral Science. Ujung Pandang: UNHAS.

Noor, N. N., (2003). Epidemologi Penyakit Menular. Makassar: UNHAS

Notoatmodjo, S. (2001). Metodologi Penelitian. Rineka Cipta : Jakarta.

Notoatmodjo, S. (2003). Ilmu Kesehatan Masyarakat : Prinsip-prinsip Dasar. Rineka Cipta : Jakarta.

Nursalam (2003). Konsepdan Penerapan Metodologi Penelitian Ilmu Keperawatan Pedoman Skripsi, Tesis dan Instrumen Penelitian Keperawatan Edisi Pertama. Salemba Medika : Jakarta.

Perau (2005). Faktor-Faktor Yang Mempengaruhi Kelangsungan Pemakaian Kontrasepsi Pil Di Kec. Sabbang Paru Kab. Wajo. Skripsi UNHAS Ujung Pandang.

Prawirohardjo, S. (2005). Ilmu Kebidanan. Yayasan Bina Pustaka : Jakarta.

Raodah (2004). Faktor-faktor yang Berhubungan Dengan Pemilihan Alat Kontrasepsi di Wilayah Kerja Puskesmas Wara Kota Palopo Tahun 2004. Skripsi FKM UNHAS. Makassar.

Safariana (2006). Faktor-faktor Yang Berhubungan Dengan Penggunaan Alat Kontrasepsi Di Kalangan Isteri TNI Kavaleri Makassar Tahun 2006. Skripsi STIK Tamalate. Makassar.

Santoso, E. B., \& Akbar, H. (2018). Faktor yang Berhubungan Dengan Kejadian ISPA Pada Balita Di Wilayah Kerja Puskesmas Juntinyuat. Hibualamo Seri Ilmu-Ilmu Alam Dan Kesehatan, 2(2), 36-40. http://journal.unhena.ac.id

Sri Wulandari. 2013. Hubungan Faktor Sosialbudaya Dengan Keikutsertaan KB IUD di Puskesmas Mergangsan Kota Yogyakarta. Jurnal Medika Respati, Vol.10 No.1 Januari 2015.

Sarce P., Sesca, D.S., Sandra, G.J.T. 2014. Faktor-Faktor yang Berhubungan dengan Penggunaan Alat Kontrasepsi dalam Rahim di Puskesmas tatelu Kabupaten Minahasa Utara. Jurnal Ilmiah Bidan, Vol.2, No.2 Juli-Desember 2014.

Santoso, B., (2005). Beberapa Efek Samping Dari Kontrasepsi : Bahan Seminar/Lokakarya Kontrasepsi. BKKBN : Jakarta.

Diterbitkan oleh:

Universitas Wiralodra

Jln. Ir. H. Juanda Km 3 Indramayu, Jawa Barat 
Sarwono, S. (2004). Pengantar Pendidikan Kesehatan Masyarakat. Jakarta : FKM UI.

Singarimbun (2006). Penduduk dan Perubahan. Jakarta : Pustaka Belajar.

Subaeda (2005). Beberapa Faktor Yang berhubungan Dengan Tingkat Kemandirian Peserta KB Di Desa Pallangga Kab. Gowa. Skripsi FK UNHAS. Makassar.

Tjokke A. Latief (2006). Suvey Prevalansi Kontrasepsi Indonesia, laporan khusus Kodya Ujung Pandang. FKM UNHAS : Makassar.

Tukan, J.S. (2003). Metode Pendidikan Seks, Perkawinan \& Keluarga. Erlangga : Jakarta.

Wahidah (2005). Gambaran Pemakaian Alat Kontrasepsi Pada Tenaga Kerja Wanita di PT. Indofood Sukses Makmur Makassar Tahun 2005. Skripsi FK UNHAS. Makassar.

Wahyuningsih, dkk. (2004). Karakteristik Akseptor Keluarga Berencana di

RW 07 Kelurahan Barombong Kecamatan Tamalatea Kota Makassar. Skripsi FK UNHAS. Makassar.

Winkjosastro, H. (2003). Dinamika Kependudukan dan KB dalam Ilmu Kebidanan. Yayasan Bina Pustaka : Jakarta.

Winkjosastro, H. (2005). Ilmu Kandungan. Yayasan Bina Pustaka : Jakarta. 